\title{
ANALISIS KUAT TEKAN BEBAS PADA PEBAMBAHAN MATOS TERHADAP STABILISASI TANAH LEMPUNG DENGAN SEMEN
}

\author{
Anwar Muda \\ Satuan Kerja Pelaksanaan Jalan Nasional II Kalimantan Tengah \\ Balai Besar Pelaksanaan Jalan Nasional XI
}

\begin{abstract}
ABSTRAK
Penelitian ini bertujuan (1). Untuk menentukan kuat tekan bebas (UCS) tanah lempung sebelum distabilisasi pasir dan semen (2). Untuk menentukan kuat tekan bebas (UCS) tanah lempung sebelum penambahan matos terhadap stabilisasi pasir dan semen. (3). Untuk menentukan kuat tekan bebas (UCS) tanah lempung setelah penambahan matos terhadap stabilisasi pasir dan semen. Metode penelitian dengan beberapa tahapan yaitu : A. Tahap persiapan. Tahap ini dilakukan (1). Menyiapkan contoh tanah lempung Desa Baringin, kota Palangka Raya. (2). Menyiapkan sampel matos, pasir dan semen. B. Tahap pelaksanaan. Pelaksanaan pengujian kuat tekan bebas dengan metode SNI 03-3638-1994. C. Tahap akhir. Tahap akhir yaitu 1. Untuk menentukan kuat tekan bebas (UCS) tanah lempung sebelum distabilisasi pasir dan semen. 2. Untuk menentukan kuat tekan bebas (UCS) tanah lempung sebelum penambahan matos terhadap stabilisasi pasir dan semen 3. Untuk menentukan kuat tekan bebas (UCS) tanah lempung setelah penambahan matos terhadap stabilisasi pasir dan semen untuk lapis perkerasan jalan raya.

Hasil penelitian menunjukkan, bahwa kuat tekan bebas (UCS) tanah lempung sebelum distabilisasi pasir dan semen sebesar $3.51 \mathrm{~kg} / \mathrm{cm}^{2}$. Kemudian, kuat tekan bebas (UCS) Pada saat $0 \%$ matos pada stabilisasi campuran $28 \%$ pasir dan $6 \%$ semen nilai UCS sebesar $9.10 \mathrm{~kg} / \mathrm{cm}^{2}$. Kemudian, pada saat $2 \%$ matos, nilai UCS makin bertambah didapatkan $10.92 \mathrm{~kg} / \mathrm{cm}^{2}$ dan bahkan $4 \%$ nilai UCS makin meningkat hingga $11.18 \mathrm{~kg} / \mathrm{cm}^{2}$. Kemudian, pada saat $6 \%$ matos nilai UCS terus makin bertambah hingga $11.44 \mathrm{~kg} / \mathrm{cm}^{2}$ dan pada penambahan $8 \%$ matos, nilai UCS terjadi peningkatan cukup besar yaitu $13.78 \mathrm{~kg} / \mathrm{cm}^{2}$. Sedangkan pada penambahan $10 \%$ matos juga mengalami kenaikan nilai UCS sebesar $14,56 \mathrm{~kg} / \mathrm{cm}^{2}$.

Berdasarkan hasil penelitian di atas, maka bahan tambah matos dapat meningkatkan nilai UCS dan memenuhi syarat sebagai subbase dan base jalan raya. Karena menurut Ingels dan Metcalf, 1972 (dalam Hardiyatmo, 2010), bahwa nilai UCS hasil $>14 \mathrm{~kg} / \mathrm{cm}^{2}$ dapat dipergunakan sebagai subbase dan base jalan raya. Sedangkan menurut Ditjen Bina Marga yang didasarkan pada SNI 03-3438-1994 (dalam Hardiyatmo, 2010), bahwa campuran ini belum dapat dipergunakan sebagai subbase dan base jalan raya, karena nilai UCS hasil $<20 \mathrm{~kg} / \mathrm{cm}^{2}$.
\end{abstract}

Kata kunci : analisis, kuat tekan bebas, matos, stabilisasi, pasir, semen 
Analisis Kuat Tekan Bebas Pada Penambahan Matos.... Anwar. M

\section{PENDAHULUAN}

\section{Latar Belakang}

Stabilisasi tanah adalah pencampuran tanah dengan bahan tertentu, guna memperbaiki sifatsifat teknis tanah atau dapat pula, stabilisasi tanah adalah usaha untuk merubah atau memperbaiki sifat-sifat teknis tanah agar memenuhi syarat teknis tertentu. Sifat-sifat teknis seperti kuat tekan bebas (UCS) tanah lempung umumnya sangat rendah. Seperti halnya, tanah lempung Ciawi (UCS) 0,65 $\mathrm{kg} / \mathrm{cm}^{2}$ (Wahjuningsih, 1997), tanah lempung Indramayu (UCS) $0,195 \mathrm{~kg} / \mathrm{cm}^{2}$ (Sudirja, 2008), tanah lempung Bukit Rawi (UCS) $0.41 \mathrm{~kg} / \mathrm{cm}^{2}$ (Muda A, 2011). Sedangkan UCS tanah lempung Baringin belum pernah dilakukan penelitian, namun dari hasil penelitian di daerah lain dimungkinkan akan mengalami hal yang sama yaitu berkisar UCS $0.00-1.00 \mathrm{~kg} / \mathrm{cm}^{2}$.

Permasalahan rendahnya kuat tekan bebas (UCS) tanah lempung disebabkan beberapa faktor diantaranya tanah lempung umumnya didominasi butiran halus sehingga mudah dipengaruhi oleh air, pada saat basah akan mengembang, dan saat kering terjadi retak-retak sehingga akan membahayakan bangunan di atasnya. Untuk itu, diperlukan suatu bahan untuk meningkatkan kuat tekannya. Pada umumnya meningkatkan kuat tekannya dilakukan berbagai cara diantaranya dengan melakukan stabilisasi terhadap tanah dengan bahan tertentu Bahan stabilisasi yang sering digunakan adalah semen, kapur, pasir dan abu terbang.

Bahan stabilisasi seperti semen sudah sering digunakan untuk lapis perkerasan jalan raya. Namun, yang menjadi permasalahan yang sering muncul adalah rendahnya nilai kuat tekan bebas (UCS). Seperti penelitian tesis yang pernah dilakukan oleh Muda, A (2011), bahwa campuran pasir $12 \%$ dengan semen $6 \%$ diperoleh nilai UCS sebesar $5.29 \mathrm{~kg} / \mathrm{cm}^{2}$, kemudian semen $8 \%$ didapatkan nilai UCS $7.33 \mathrm{~kg} / \mathrm{cm}^{2}$ dan semen $10 \%$ diperoleh nilai UCS sebesar $9.06 \mathrm{~kg} / \mathrm{cm}^{2}$, sehingga tanah ini belum memenuhi persayaran teknis lapis perkerasan jalan raya, karena nilai UCS masih $\leq 20$ $\mathrm{kg} / \mathrm{cm}^{2}$ (Hardiyatmo, 2010).

Dengan bahan stabilisasi semen hingga $10 \%$, dianggap sudah tidak efesien sebagai bahan lapis perkerasan jalan raya, maka perlu dilakukan untuk meningkatkan kuat tekan bebas (UCS) dengan bahan tambah terhadap stabilisasi tanah lempung dengan semen. Bahan tambah yang pernah dilakukan oleh Hasanuddin (2011) dalam penelitian tesisnya yang berjudul "Analisis Pemakaian Matos Sebagai Bahan Tambah Pada Stabilisasi Tanah Lempung Dengan Kapur”. Hasil penelitiannya menunjukkan, bahwa dari pengujian kuat tekan bebas (UCS) yang dilakukan pemeraman nilai $\mathrm{q}_{\mathrm{u}}$ terus meningkat seiring dengan bertambahnya kadar kapur+matos pada tanah. Peningkatan tertinggi juga terjadi pada penambahan $14 \%$ kapur $+5 \%$ matos pada umur pemeraman 14 hari yaitu sebesar $22.32 \mathrm{~kg} / \mathrm{cm}^{2}$. Dari hasil penelitian ini, tanah memenuhi syarat teknis lapis perkerasan jalan raya karena nilai UCS hasil $22.32 \mathrm{~kg} / \mathrm{cm}^{2} \geq 22 \mathrm{~kg} / \mathrm{cm}^{2}$ (spesifikasi bina marga).

Melihat permasalahan di atas, pada penelitian ini akan dicoba untuk meningkatkan kuat tekan bebas (UCS) tanah lempung dengan bahan tambah matos terhadap stabilisasi tanah lempung dengan semen untuk lapis perkerasan jalan raya. Tanah lempung cocok dicampur dengan semen, jika Indeks Plastisitas (PI) tanah lempung $\leq$ $10 \%$, maka untuk menurunkan PI tanah lempung, akan dilakukan pencampuran dengan pasir dengan proporsi 12, 16, 20, 24 dan $28 \%$ terhadap berat kering tanah lempung diharapkan Indeks Plastisitas (PI) $\leq 10 \%$.

Selanjutnya dilakukan proses pencampuran tanah, pasir dan proses berikutnya dengan mencampur semen. dan matos. Matos adalah bahan aditif yang berfungsi memadatkan (solidifikasi) dan menstabilkan tanah secara fisik dan kimiwi.(www.matos.co.id). Oleh karena itu, untuk memahami beberapa prinsip dalam penggunaan matos dengan deskripsi membuat campuran tanah + semen, kemudian menyebar secara merata dengan komposisi $1 \mathrm{~m}^{3}$ tanah: semen $(2-8 \%$ dari berat tanah) kemudian membuat solusi matos zat terlarut ke dalam air dan aduk dengan komposisi sebagai berikut (untuk tanah $1 \mathrm{~m} 3$ ) : $1 \mathrm{~kg}$ matos + Air ** pada kadar air optimum (http://matos.co.id).

\section{KAJIAN PUSTAKA}

\section{Landasan Teori}

\section{a. Contoh Tanah}

SNI 1742:2008 menyatakan bahwa contoh tanah yang akan digunakan untuk pemadatan di laboratorium adalah tanah yang lolos saringan no. 
4 (4.75 mm). Sedangkan contoh tanah yang digunakan untuk pemadatan dengan Model Pendekatan Alat Uji Kepadatan Ringan Untuk Tanah di Laboratorium ini sama dengan contoh tanah SNI 1742:2008 yaitu tanah lolos saringan no. $4(4.75 \mathrm{~mm})$.

\section{b. Berat jenis (Gs)}

Berat jenis tanah adalah angka perbandingan antara berat butir tanah $(\gamma \mathrm{s})$ dan berat air suling $(\gamma \mathrm{w})$ dengan isi yang sama pada suhu $4^{0} \mathrm{C}$. Pengujian ini dimaksudkan sebagai acuan dalam pengujian berat jenis (specific gravity) dengan tujuan untuk memperoleh besaran (angka) berat jenis tanah yang akan digunakan selanjutnya untuk penentuan parameter lainnya seperti sifat tanah (SNI 03-1964-1990), seperti pada persamaan 2.1.

$$
G_{\mathrm{s}}=\frac{\gamma S}{\gamma w} \ldots \ldots \ldots \ldots \ldots \ldots \ldots \ldots \ldots \ldots \ldots \ldots \ldots
$$

Berat jenis $\left(G_{s}\right)$ tidak berdimensi. Secara tipikal, berat jenis berbagai tanah berkisar antara 2,65 sampai 2,75 . Berat jenis $G_{s}=2,67$ biasanya digunakan untuk tanah-tanah tidak berkohesi atau tanah granular, sedangkan untuk tanah-tanah tidak kohesif tidak mengandung bahan organik Gs berkisar diantara 2,68 sampai 2,72. Nilai-nilai berat jenis dari berbagai jenis tanah diberikan dalam Tabel 2.1

Tabel 2.1 Berat jenis tanah (specific gravity)

\begin{tabular}{|l|c|}
\hline \multicolumn{1}{|c|}{ Macam tanah } & Berat jenis (Gs) \\
\hline \hline Kerikil & $2,65-2,68$ \\
\hline Pasir & $2,65-2,68$ \\
\hline Lanau organik & $2,62-2,68$ \\
\hline Lempung organik & $2,58-2,65$ \\
\hline Lempung anorganik & $2,68-2,75$ \\
\hline Humus & 1,37 \\
\hline Gambut & $1,25-1,28$ \\
\hline
\end{tabular}

Sumber: Hardiyatmo (2012)

\section{c. Pemadatan}

Untuk menentukan hubungan kadar air dengan berat volume dan untuk mengevaluasi tanah agar memenuhi persyaratan kepadatan, maka umumnya dilakukan uji pemadatan. Menurut Proctor, 1933 (dalam Hardiyatmo, 2012), telah mengamati bahwa ada hubungan yang pasti antara kadar air dan berat volume kering tanah padat. Untuk berbagai jenis tanah pada umumnya, terdapat satu nilai kadar air optimum tertentu untuk mencapai berat volume kering maksimumnya. Hubungan berat volume kering $(\gamma \mathrm{d})$ dengan berat volume basah $(\gamma b)$ dan kadar air $(w)$ dinyatakan dalam Persamaan 2.2.

$$
\gamma d=\frac{\gamma b}{1+w} \ldots \ldots \ldots \ldots \ldots \ldots \ldots \ldots . .2 .2
$$

Karateristik kepadatan tanah dapat dinilai dari pengujian standar di laboratorium yang disebut standar Proctor. Prinsip pengujiaan menggunakan pemadat berupa silinder mould yang mempunyai volume $9,44 \times 10^{-4} \mathrm{~m}^{3}$. Tanah di dalam mould dipadatkan dengan penumbuk yang beratnya $2.50 \mathrm{~kg}$ dengan tinggi jatuh $30,50 \mathrm{~cm}$. Tanah dipadatkan dalam tiga lapisan dengan tiap lapisan ditumbuk 25 kali. (Hardiyatmo, 2012)

Dalam uji pemadatan, percobaan di ulang paling sedikit 5 kali dengan kadar air tiap percobaan divariasikan. Kemudian, digambarkan sebuah grafik hubungan kadar air dan berat volume keringnya. Kurva yang dihasilkan pada Gambar 2.3 dari pengujian memperlihatkan nilai kadar air terbaik (w opt) untuk mencapai berat volume kering terbesar atau kepadatan kering maksimum ( $\gamma \mathrm{d}$ maks).

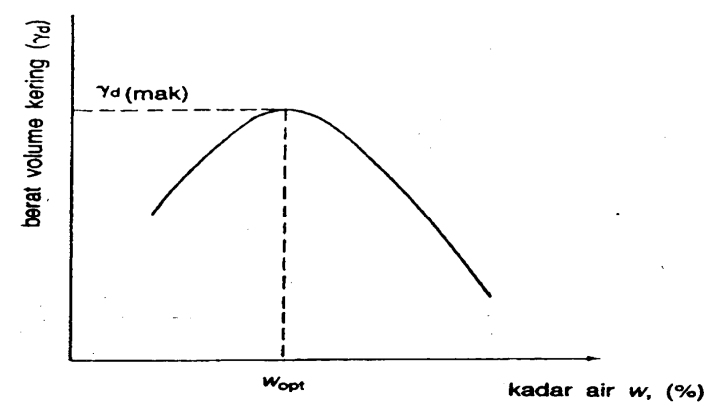

Gambar 2.3 Kurva hubungan kadar air dan berat volume kering Sumber: Hardiyatmo, 2012

Kemungkinan berat volume kering maksimum dinyatakan sebagai berat volume kering dengan tanpa rongga udara (zero air void) atau berat volume kering saat tanah menjadi jenuh ( $\gamma z a v)$ dapat dihitung pada Persamaan 2.3.

$$
\gamma z a v=\frac{G s \cdot \gamma w}{1+w \cdot G s} \ldots \ldots \ldots \ldots \ldots \ldots \ldots
$$


Sedangkan SNI 1742:2008 menyatakan bahwa kadar air yang paling cocok untuk cara pemadatan tertentu yang menghasilkan kepadatan paling besar yang diperoleh dari kurva pemadatan. Kemudian dari pemadatan tersebut kemungkinan udara dalam tanah akan keluar, maka tanah dalam kondisi jenuh air (kepadatan kering jenuh), tetapi dalam kondisi ini sulit tercapai. Sehingga, kepadatan kering jenuh merupakan perbandingan antara massa kering tanah dan volume total pada kondisi jenuh air (rongga berisi udara nol) kondisi jenuh air (rongga berisi udara nol).

\section{d. Semen Portland}

Adapun standar kualitas semen yang digunakan untuk stabilisasi tanah adalah semen jenis tipe I. Semen jenis ini merupakan semen Portland biasa (Ordinary Portland Cement) digunakan untuk bangunan-bangunan pada umumnya, dimana tidak ada persyaratan khusus. Rollings dan Rollings, 1996 (dalam Hardiyatmo, 2010).

Semen Portland merupakan media perekat bila bereaksi dengan air. Media perekat ini kemudian memadat dan membentuk massa keras. Pada proses hidrasi tersebut, hasil hidrasi akan mengendap di bagian luar sedang di bagian dalam akan terhidrasi secara bertahap sehingga volumenya mengecil (Hardiyatmo, 2010).

Semen Gresik (Persero), merupakan perseroan memproduksi berbagai jenis semen. Semen utama yang diproduksi adalah semen Portland tipe I (OPC) dimana keunggulan dari semen ini, di sampin g sebagai bahan hidrolis berupa serbuk halus yang dapat mengeras apabila tercampur dengan air, juga penggunaannya dipakai secara luas untuk konstruksi umum, seperti konstruksi bangunan yang tidak memerlukan persyaratan khusus, antara lain bangunan perumahan, gedung-gedung bertingkat, jembatan, landasan pacu dan jalan raya (Semen Gresik, 2010).

\section{e. Stabilisasi menggunakan pasir}

Stabilisasi menggunakan campuran pasir bertujuan untuk mengukur perubahan indeks plastisitas (PI). Hicks, 2002 (dalam Hardiyatmo, 2010) menyebutkan, tanah berbutir halus seperti lempung jika distabilisasi dengan semen sebaiknya tanah tersebut bila uji saringan No. $200 \geq 25 \%$ maka indeks plastisitas $(\mathrm{PI}) \leq 10 \%$. Jika tanah tersebut bila uji saringan No. $200<25 \%$ maka indeks plastisitas $(\mathrm{PI}) \leq 10 \%$ atau $\mathrm{PI} \geq 10 \%$ atau PI $\leq 6$ (PI x persen lolos saringan No. $200 \leq 60$ seperti pada Tabel 2.2.

Tabel 2.2 Petunjuk awal untuk pemilihan metode stabilisasi

\begin{tabular}{|c|c|c|c|c|c|c|}
\hline $\begin{array}{l}\text { Material lolos } \\
\text { saringan No.zoo }\end{array}$ & \multicolumn{3}{|c|}{$\begin{array}{l}225 \% \text { 1olos saringan } \\
\text { No. } 200(0.075 \mathrm{~mm})\end{array}$} & \multicolumn{3}{|c|}{$\begin{array}{l}<25 \% \text { lolos saringan } \\
\text { No. } 200(0.075 \mathrm{~mm})\end{array}$} \\
\hline $\begin{array}{l}\text { Indeks plastisitas } \\
\text { PI }(\%)\end{array}$ & $\leq 10$ & $\begin{array}{c}10- \\
20\end{array}$ & $\geq 20$ & $\begin{array}{c}\leq 6 \text { (PI)x } \\
\text { persen } \\
\text { 1olos } \\
\text { saringan } \\
\text { No.200 } \\
\leq 60\end{array}$ & $\leq 10$ & $\geq 10$ \\
\hline \multicolumn{7}{|l|}{ Bentuk stabilisasi } \\
\hline $\begin{array}{l}\text { Semen dan } \\
\text { campuran } \\
\text { pengikat }\end{array}$ & Cocok & Ragu & $\begin{array}{l}\text { Tidak } \\
\text { cocoke }\end{array}$ & Cocok & Cacok & Cocok \\
\hline Kapur & Ragu & Cocok & $\begin{array}{l}\text { Tidak } \\
\text { coccok }\end{array}$ & $\begin{array}{l}\text { Tidak } \\
\text { concok }\end{array}$ & Ragu & Cocok \\
\hline Aspal (bitumen) & Ragu & Ragu & $\begin{array}{l}\text { Tidak } \\
\text { cocook }\end{array}$ & Cocok & Cacok & Ragu \\
\hline $\begin{array}{l}\text { Aspal/semen } \\
\text { dicampur }\end{array}$ & Ragu & Ragu & $\begin{array}{l}\text { Tidalk } \\
\text { cocolk }\end{array}$ & Cocok: & Cacok & Ragu \\
\hline Granular & Cocok & $\begin{array}{l}\text { Tidak } \\
\text { cocok }\end{array}$ & $\begin{array}{l}\text { Tidak } \\
\text { cocook }\end{array}$ & Cocok & Cocok & Ragu \\
\hline $\begin{array}{l}\text { Lain-lain } \\
\text { campuran }\end{array}$ & $\begin{array}{l}\text { Takk } \\
\text { cocolk }\end{array}$ & Cocok & Cocole & Ragu & Ragu & Cocole \\
\hline
\end{tabular}

Sumber : Hicks, 2002 (dalam Hardiyatmo, 2010)

\section{f. Stabilisasi menggunakan semen}

Kriteria stabilisasi tanah menggunakan semen semen yang diusulkan oleh Ingels dan Metcalf (1972) dalam Tabel 2.3 dan criteria kekuatan tanah semen untuk Lapis Pondasi Bawah (LPB) dan Lapis Pondasi Atas (LPA) oleh Ditjen Bina Marga yang didasarkan pada SNI 03-34381994 (dalam Hardiyatmo, 2010) dalam Tabel 2.4 berikut.

Tabel 2.3 Kriteria stabilisasi tanah semen

\begin{tabular}{|c|c|c|c|c|c|}
\hline \multirow[t]{2}{*}{ Purpose } & \multicolumn{2}{|c|}{ U.C.S."I) } & \multirow[t]{2}{*}{ C.8.R. ${ }^{[2]}$} & \multirow{2}{*}{\begin{tabular}{|l} 
Swell \\
per cent
\end{tabular}} & \multirow{2}{*}{$\frac{\begin{array}{c}\text { Loss in } \\
\text { wet/dry test }\end{array}}{\text { per cent }}$} \\
\hline & $\mathrm{kg} / / \mathrm{cm}^{2}$ & $\left(i b / / i^{2}\right)$ & & & \\
\hline $\begin{array}{l}\text { Road sub-base, formation } \\
\text { backill for trenches etc. } \\
\text { Road sub-base, base for } \\
\text { light traffic }{ }^{[4]} \\
\text { Base for heavy traftic }{ }^{(4)} \\
\text { Building blocks } \\
\text { Embankment protection } \\
\text { Floodways (too strong for } \\
\text { general use under thin } \\
\text { surfacings) }\end{array}$ & $\begin{array}{c}3.5 \cdot 10.5 \\
7 \cdot 14 \\
14 \cdot 56\end{array}$ & $\begin{array}{l}(50-150) \\
(100-200) \\
(200-800)\end{array}$ & $\begin{array}{c}20.80 \\
50.150 \\
200 \cdot 600\end{array}$ & $\begin{array}{l}2 \\
2\end{array}$ & $\begin{array}{l}7 \\
10\end{array}$ \\
\hline \multicolumn{6}{|c|}{$\begin{array}{l}\text { (II) U.C.S. cured seven days at constant moisture content. The loss of strength on } \\
\text { soaking should not be more than } 20 \text { per cent. }\end{array}$} \\
\hline \multicolumn{6}{|c|}{ C.B.R. - Soaked four days. } \\
\hline \multicolumn{6}{|c|}{$\begin{array}{l}\text { Durability lest appropriate only where moisture penetration is likely to occur } \\
\text { Higher cement contents may be required to meet this criterion. }\end{array}$} \\
\hline (4) Lower strengths ma & e ade & efor we & drainec & reas in & ropics. \\
\hline
\end{tabular}

Sumber: Ingels dan Metcalf (1972) 
Tabel 2.4 Kriteria kekuatan stabilisasi tanah semen

\begin{tabular}{|l|c|c|}
\hline Uraian & $\begin{array}{c}\text { Kuat tekan } \\
\text { bebas } \\
\left(\mathrm{kg} / \mathrm{cm}^{2}\right)\end{array}$ & $\begin{array}{c}\text { CBR } \\
(\%)\end{array}$ \\
\hline \hline $\begin{array}{l}\text { Lapis Pondasi Atas (LPA), } \\
\text { peram 7 hari }\end{array}$ & 22 & 80 \\
\hline $\begin{array}{l}\text { Lapis Pondasi Bawah (LPB), } \\
\text { peram 3 hari dan rendam 4 hari }\end{array}$ & 6 & 20 \\
\hline
\end{tabular}

Sumber: Hardiyatmo (2010)

\section{g. Bahan tambah matos pada stabilisasi tanah lempung dengan semen}

Penggunaan bahan tambah matos adalah meningkatkan parameter daya dukung tanah (pengganti base dan subbase, sekaligus stabilisasi tanah dasar badan jalan. Sifat-sifat campuran untuk perkerasan jalan raya disyaratkan seperti pada Tabel 2.5 berikut.

Tabel 2.5 Sifat-sifat campuran bahan tambah Matos

\begin{tabular}{|l|c|c|c|c|}
\hline \multirow{2}{*}{$\begin{array}{c}\text { Penguji } \\
\text { an }\end{array}$} & \multicolumn{2}{|c|}{$\begin{array}{c}\text { Batas-batas sifat setelah } \\
\text { perawatan }\end{array}$} & $\begin{array}{c}\text { Metode } \\
\text { penguji } \\
\text { an }\end{array}$ \\
\cline { 2 - 4 } & $\begin{array}{c}\text { Minim } \\
\text { um }\end{array}$ & $\begin{array}{c}\text { Targ } \\
\text { et }\end{array}$ & $\begin{array}{c}\text { Maksim } \\
\text { um }\end{array}$ & \\
\hline $\mathrm{UCS}$ & 20 & 24 & 35 & $\begin{array}{c}\text { ASTM } \\
\text { D1633- } \\
63\end{array}$ \\
$\mathrm{~kg} / \mathrm{cm}^{2}$ & & & & $\begin{array}{c}\text { SNI } \\
03- \\
1744- \\
\text { CBR \% }\end{array}$ \\
& 100 & 120 & 200
\end{tabular}

Sumber: Spesifikasi Teknik Bina Marga

\section{h. Standar kualitas air}

Air yang digunakan untuk stabilisasi dengan semen harus bersih, tidak mengandung asam, alkali, bahan organik, minyak, sulfat dan klorida di atas nilai yang diijinkan, Ingels dan Metcalf, 1972 (dalam Hardiyatmo, 2010). Namun pada penelitian ini, digunakan kualitas air PDAM atau air sungai jernih berdasarkan pengujian tingkat keasaman $\mathrm{pH}$ 4,5 - 8,5 seperti pada Tabel 2.6 berikut.
Tabel 2.6 Standar kualitas air terstabilisasi

\begin{tabular}{|c|l|c|c|}
\hline No & $\begin{array}{c}\text { Macam } \\
\text { pengujian }\end{array}$ & Acuan & Nilai ijin \\
\hline \hline 1 & pH & $\begin{array}{c}\text { AASHTO } \\
\text { T 26-79 }\end{array}$ & $4,5-8,5$ \\
\hline 2 & $\begin{array}{l}\text { Bahan } \\
\text { organik }\end{array}$ & $\begin{array}{c}\text { AASHTO } \\
\text { T 26-79 }\end{array}$ & $\begin{array}{c}\text { Maks. } \\
2.00 O \text { ppm }\end{array}$ \\
\hline 3 & $\begin{array}{l}\text { Minyak } \\
\text { mineral }\end{array}$ & $\begin{array}{c}\text { SNI 06- } \\
\text { 2502-1991 }\end{array}$ & $\begin{array}{c}<2 \% \text { berat } \\
\text { semen }\end{array}$ \\
\hline 4 & $\begin{array}{l}\text { Ion sulfat } \\
\text { (Na2SO4) }\end{array}$ & $\begin{array}{c}\text { SNI 06- } \\
2426-1991\end{array}$ & $\begin{array}{c}<10 \text {.OOO } \\
\text { ppm }\end{array}$ \\
\hline 5 & $\begin{array}{l}\text { Ion klorida } \\
\text { (NaC1) }\end{array}$ & $\begin{array}{c}\text { SNI 03- } \\
2431-1991\end{array}$ & $\begin{array}{c}<20 \text { OOOO } \\
\text { ppm }\end{array}$ \\
\hline
\end{tabular}

Sumber : Hardiyatmo (2010)

\section{Studi Pustaka}

\section{a. Hasanuddin (2011)}

Hasanuddin (2011) melakukan penelitian tesis yang berjudul "Analisis Pemakaian Matos Sebagai Bahan Tambah Pada Stabilisasi Tanah Lempung Dengan Kapur", menyatakan bahwa tanah Desa Jalan Budi Luhur, Simpang Tangor, Kecamatan Tenayan Raya, Kota Pekanbaru merupakan tanah berlempung plastis tinggi (PI) $32,76 \%$. Kemudian, tanah ini memiliki nilai daya dukung tanah dengan nilai CBR sebesar $11.35 \%$ dan kuat tekan bebas (UCS) sebesar $3 \mathrm{~kg} / \mathrm{cm}^{2}$ sehingga relatif baik untuk subgrade jalan raya.

Setelah penambahan kapur dan matos pada tanah asli dapat merubah daya dung tanah (CBR) dan kuat tekan bebas (UCS). Dari hasil pengujian CBR pemeraman 7 hari dan 14 hari nilai CBR akan meningkat seiring bertambahnya kapur dan matos pada tanah. Peningkatan tertinggi terjadi penambahan $14 \%$ kapur $+5 \%$ matos pada umumr pemeraman 14 hari sebesar $54.70 \%$. Sedangkan pada pengujian kuat tekan bebas (UCS) yang dilakukan pemeraman, nilai UCS terus meningkat seiring bertambahnya kapur dan matos pada tanah. Peningkatan tertinggi juga terjadi pada penambahan $14 \%$ kapur $+5 \%$ matos pada pemeraman 14 hari sebesar $22.32 \mathrm{~kg} / \mathrm{cm}^{2}$. Dari hasil pengujian CBR sebesar 54.70\%, maka tanah yang distabilisasi ini dapat digunakan sebagai Base Course, karena peraturan Bina Marga untuk Base Course CBR $\geq 50 \%$, sedangkan untuk Subbase Course $\geq 20 \%$.

\section{b. Teguh Widodo dan Rahmat Imron Qosan (2011)}

Teguh Widodo dan Rahmat Imron Qosari (2011) melakukan penelitian berjudul "Efektifitas 
Penambahan Matos Pada Stabilisasi Semen Tanah Berbutir Halus", yang dipublikasikan pada Jurnal Teknik Volume 1, Nomor 2, Oktober 2011, ISSN 2088-3676, Jurusan Teknik Sipil Universitas Janabadra, Yogyakarta, menyatakan bahwa tanah dari Dukuh Perengdawe, Desa Balecatur, Kecamatan Gamping, Kabupaten Sleman merupakan tanah yang memiliki kandungan butiran halus > 50\%, batas cair > 50\% dan platisitas indeks (PI) $25.59 \%$ sehingga tanah ini termasuk golongan lempung palstisitas tinggi.

Pada pengujian penambahan matos terlihat, peningkatan nilai UCS tanah-semen-matos terhadap nilai nilai UCS tanah semen adalah $9.74 \%$ (penambahan semen 4\%), $13.58 \%$ (penambahan semen $8 \%$ ) dan $17.25 \%$ (penambahan semen $12 \%$ ). Peningkatan nilai UCS yang relatif kecil menunjukkan penambahan $1 \mathrm{~kg} / \mathrm{m}^{3}$ tanah pada stabilisasi tanah semen kurang efektif. Hal ini disebabkan oleh luas permukaan butiran halus yang sangat besar dan struktur lempung yang memiliki empat tingkatan struktur lempung mengakibatkan jumlah matos yang diperlukan untuk melarutkan humus lebih besar.

\section{c. Anwar Muda (2011)}

Anwar Muda (2011), melakukan penelitian tesis "Stabilisasi Tanah Lempung Bukit Rawi Menggunakan Pasir dan Semen" bahwa tanah Bukit Rawi memiliki sifat lempung organik, plastisitas rendah, kondisi padat $1,43 \mathrm{gr} / \mathrm{cm} 3$ pada kadar air optimum $24,27 \%$. Tanah ini memiliki nilai CBR $3.57 \%<5 \%$ sehingga penilaian sebagai tanah dasar (subgrade) buruk. Dalam uji kuat tekan bebas diperoleh UCS sebesar $0.47 \mathrm{~kg} / \mathrm{cm}^{2}$ sehingga tanah tergolong tanah dengan konsistensi lempung lunak karena nilai UCS tanah diantara $0.25-0.50$ $\mathrm{kg} / \mathrm{cm}^{2}$.

Setelah dilakukan stabilisasi dengan campuran pasir 12 , 16 , dan $20 \%$ nilai PI turun $\leq 10 \%$ sehingga memenuhi syarat distabiliasi dengan semen. Campuran 10\% semen dengan 20\% pasir nilai CBR dan UCS naik cukup besar dengan nilai CBR $135 \%>5 \%$ dan UCS $16.44 \mathrm{~kg} / \mathrm{cm}^{2}$ sehingga terpenuhi subgrade dan subbase jalan jalan raya (CBR > 5\%) dan belum memenuhi syarat base jalan raya $\left(\mathrm{UCS}<20 \mathrm{~kg} / \mathrm{cm}^{2}\right.$.

\section{METODE PENELITIAN}

Proses tahapan penelitian seperti bagan alir pada
Gambar 3.1 berikut ini:

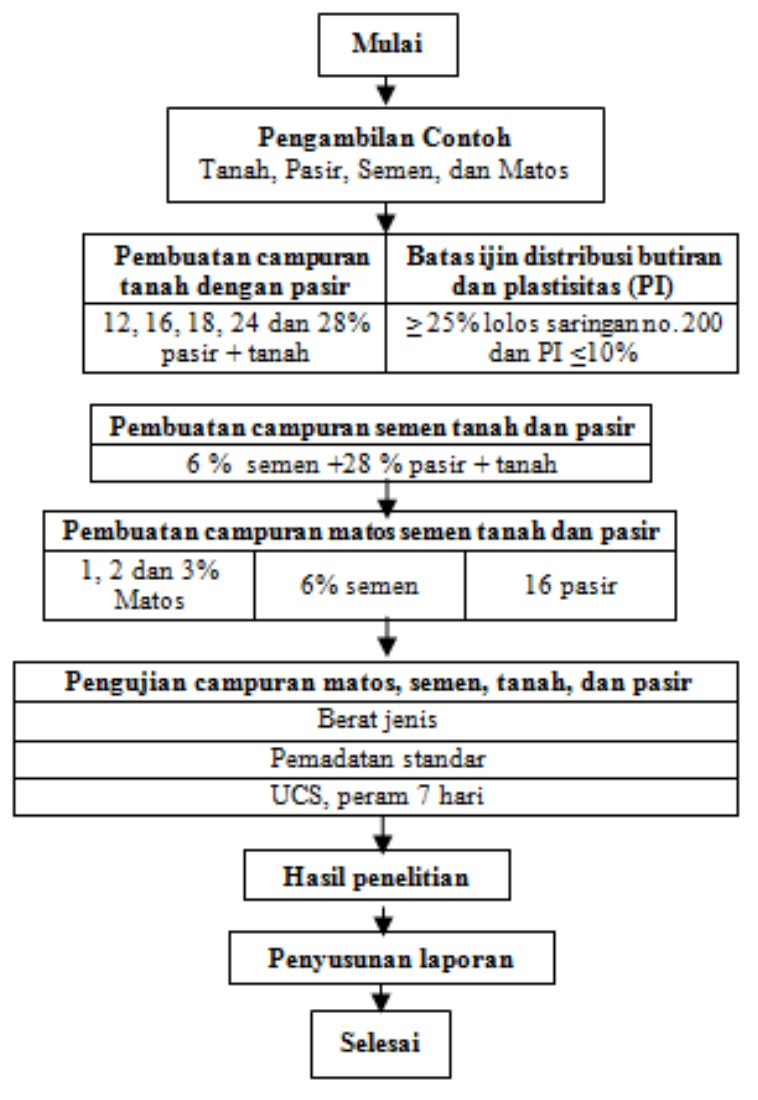

Gambar 3.1 Bagan Alir Penelitian

\section{Pengambilan contoh}

\section{a. Tanah}

Contoh tanah jenis lempung diambil pada ruas jalan Palangkaraya-Bukit Rawi tepatnya di Desa Baringin, Kota Palangkaraya. Kemudian, tanah ini dijemur hingga kering udara dan disaring dengan saringan No. 4. Contoh saringan No. 4 ini dimaksudkan agar pengujian tidak ada gumpalangumpalan yang lebih besar dari saringan No. 4 .

\section{b. Pasir}

Pasir digunakan dengan tujuan diharapkan dapat menurunkan nilai indeks plastisitas (PI). Jika $\geq 25 \%$ lolos saringan no. 200 dan PI $\leq 10 \%$ atau $\leq$ $25 \%$ lolos saringan no. 200 dan PI $\geq 10 \%$ atau PI $\leq$ 10. maka tanah memenuhi syarat distabilisasi dengan semen. 


\section{c. Semen}

Contoh semen yang digunakan adalah semen Portland produksi semen Gresik sebanyak 1 zak $(50 \mathrm{~kg})$

\section{d. Matos}

Contoh matos digunakan adalah PT. Watukali Capita Ciptama, Yogyakarta yang berfungsi untuk memadatkan (solidifikasi) dan mestabilkan (stabilizer) tanah secara fisik - kimia. Matos berupa material serbuk halus terdiri dari komponen mineral anorganik. Untuk stabilisasi tanah menggunakan dari matos dikombinasikan dengan semen Portland. Untuk itu, beberapa prinsip dalam penggunaan matos sebagai berikut:

a. Membuat campuran tanah + semen, kemudian menyebar secara merata. Dengan komposisi $1 \mathrm{~m}^{3}$ dari tanah: semen (2-8\% dari berat tanah)

b. Membuat solusi dengan komposisi sebagai berikut (untuk tanah $1 \mathrm{~m} 3$ ): $1 \mathrm{~kg}$ MATOS+ Air pada kadar air optimum (http:///Matos_Soil_Stabilizer.html diakses 5/6/2016)

\section{Pembuatan campuran tanah dan pasir}

Pembuatan campuran tanah dan pasir bertujuan untuk menurunkan indeks plastisitas (PI). Proporsi campuran pasir $12 \%$ diharapkan mendapatkan PI $\leq 10 \%$, maka tanah cocok distabilisasi dengan semn.

\section{Pembuatan campuran semen tanah dan pasir}

Pembuatan campuran semen, tanah dan pasir bertujuan untuk untuk menentukan nilai UCS sebelum penambahan matos. Proporsi campuran semen $6 \%$ dan dicampur dengan $12 \%$ pasir PI $\leq$ $10 \%$ serta tanah lempung.

\section{Pembuatan campuran matos semen tanah dan pasir}

Pembuatan campuran bahan tambah matos, semen, tanah dan pasir bertujuan untuk untuk menentukan kuat tekan bebas (UCS) untuk lapis perkerasan jalan raya. Proporsi campuran matos 1 $\mathrm{kg} / \mathrm{m}^{3}$ dengan semen $6 \%$ semen, pasir $16 \%$ dan tanah lempung.

\section{HASIL DAN PEMBAHASAN}

\section{Hasil Penelitian}

\section{a. Tanah lempung sebelum penambahan matos terhadap stabilisasi dengan semen}

Adapun karakteristik tanah lempung Desa Baringin, Kota Palangka Raya dapat dilihat pada Tabel 4.1 berikut.

Tabel 4.1 Karakteristik tanah lempung Desa Baringin Kota Palangka Raya

\begin{tabular}{|l|c|c|}
\hline \multicolumn{1}{|c|}{ Tipe pengujian } & Satuan & Hasil \\
\hline $\begin{array}{l}\text { Ukuran butir lolos no. } \\
\text { UOO }\end{array}$ & $\%$ & 88.53 \\
\hline Batas cair & $\%$ & 41.11 \\
\hline Batas plastis & $\%$ & 25.66 \\
\hline Indeks plastisitas (PI) & $\%$ & 15.45 \\
\hline Berat jenis & & 2.63 \\
\hline $\begin{array}{l}\text { Berat isi kering } \\
\text { maksimum }\end{array}$ & $\mathrm{gr} / \mathrm{cm}^{3}$ & 1.52 \\
\hline Kadar air optimum & $\mathrm{kg} / \mathrm{cm}^{2}$ & 3.51 \\
\hline UCS & & 23.61 \\
\hline
\end{tabular}

Sumber : Hasil analisis (2016)

\section{b. Tanah lempung distabilisasi dengan pasir}

Stabilisasi tanah lempung dengan pasir bertujuan untuk mendapatkan nilai indeks plastisitas $(\mathrm{PI}) \leq 10 \%$. Disini tanah distabilisasi dengan pasir $12 \%$ dan diharapkan diperoleh Indek Plastisitas $(\mathrm{PI}) \leq 10 \%$, maka tanah cocok distabilisasi dengan semen. Adapun nilai indeks plastisitas (PI) seperti pada Tabel 4.2 berikut.

Tabel 4.2 Indeks plastisitas (PI) campuran tanah dengan pasir

\begin{tabular}{|l|c|c|c|c|c|c|}
\hline $\begin{array}{l}\text { Campu } \\
\text { ran } \\
\text { pasir }\end{array}$ & $\%$ & 12 & 16 & 20 & 24 & 28 \\
\hline $\begin{array}{l}\text { Indeks } \\
\text { Plastisit } \\
\text { as (PI) }\end{array}$ & $\%$ & 12.86 & 12.30 & 11.03 & 10.76 & 9.20 \\
\hline
\end{tabular}

Sumber: Hasil analisis (2016) 


\section{c. Kuat Tekan Bebas Sebelum Penambahan Matos}

Kuat tekan bebas (UCS) sebelum penambahan matos terhadap stabilisasi tanah lempung, pasir dan semen seperti pada Tabel 4.3 berikut :

Tabel 4.3 UCS sebelum penambahan matos

\begin{tabular}{|c|c|c|c|}
\hline $\begin{array}{c}\text { Campuran } \\
\text { Matos } \\
(\%)\end{array}$ & $\begin{array}{c}\text { Campura } \\
\text { n pasir } \\
(\%)\end{array}$ & $\begin{array}{c}\text { Campura } \\
\text { n semen } \\
(\%)\end{array}$ & $\begin{array}{c}\mathrm{UCS} \\
\left(\mathrm{kg} / \mathrm{cm}^{2}\right. \\
)\end{array}$ \\
\hline 0 & 28 & 6 & 9.10 \\
\hline
\end{tabular}

Sumber : Hasil analisis (2016)

\section{d. Kuat Tekan Bebas Setelah Penambahan Matos}

Kuat tekan bebas (UCS) setelah penambahan matos terhadap stabilisasi tanah lempung, pasir dan semen seperti pada Tabel 4.4 berikut :

Tabel 4.4 UCS setelah penambahan matos

\begin{tabular}{|c|c|c|c|}
\hline $\begin{array}{c}\text { Campuran } \\
\text { Matos } \\
(\%)\end{array}$ & $\begin{array}{c}\text { Campur } \\
\text { an pasir } \\
(\%)\end{array}$ & $\begin{array}{c}\text { Campura } \\
\text { n semen } \\
(\%)\end{array}$ & $\begin{array}{c}\text { UCS } \\
\left(\mathrm{kg} / \mathrm{cm}^{2}\right)\end{array}$ \\
\hline 2 & 28 & 6 & 10.20 \\
\hline 4 & 28 & 6 & 11.18 \\
\hline 6 & 28 & 6 & 11.44 \\
\hline 8 & 28 & 6 & 13.78 \\
\hline 10 & 28 & 6 & 14.56 \\
\hline
\end{tabular}

Sumber : Hasil analisis (2016)

\section{Pembahasan}

\section{Tanah lempung sebelum penambahan matos terhadap stabilisasi dengan semen}

\section{a. Ukuran Butir Lolos No. 200}

Berdasarkan Tabel 4.1 di atas, bahwa distribusi ukuran butir dengan analisa saringan (sieve analysis) bahwa distribusi ukuran butir tanah yang lolos saringan No. 200 sebesar $88.53 \%$. Hal ini menunjukkan bahwa prosentasi butiran halus sangat dominan. Menurut (Hardiyatmo, 2012), bahwa tanah ini termasuk berbutir halus dengan jenis lanau atau lempung, karena tanah yang termasuk berbutir halus jika tanah tersebut lolos saringan no. $200>50 \%$.

\section{b. Indeks Plastisitas (PI)}

Indeks plastisitas (PI) diperoleh dari pengujian batas-batas Atterberg yaitu selisih batas cair (LL) dan batas plastis PL). Pada pengujian ini diperoleh batas cair (LL) pada $\mathrm{x}=25$ ketukan adalah $41.11 \%$ dan batas plastis (PL) saat terjadi retak-retak mendekati diameter gulungan $3 \mathrm{~mm}$ adalah $25.66 \%$ sehingga diperoleh indeks plastisitas (PI) 15,45 \%. Menurut AASHTO, bahwa tanah ini termasuk tanah berlempung dengan penilaian umum sebagai tanah dasar sedang sampai buruk. Hal ini dikarenakan plastisitas (PI) sampel tanah > 11\% dan batas plastis (PL) $15,45 \%<30 \%$ sehingga termasuk dalam kelompok A-7-6. Kemudian, menurut Hardiyatmo (2010) tanah ini tidak cocok distabilisasi dengan semen karena PI > 10\%. Untuk itu, tanah dilakukan penurunan PI dengan stabilisasi dengan pasir $12 \%$.

\section{c. Berat Jenis (Gs)}

Hasil pengujian berat jenis (Gs) tidak terlalu jauh. Jika diambil rata-rata didapatkan berat jenis 2,63. Jika dilihat besaran nilai berat jenis (Gs) ini umumnya termasuk jenis lempung. Menurut Hardiyatmo (2006), bahwa tanah ini termasuk jenis tanah mengandung lempung organik karena setiap tanah yang mempunyai berat jenis (Gs) 2,58 - 2,65 maka tanah tersebut termasuk jenis lempung organik.

\section{d. Pemadatan}

Hasil pemadatan menggunakan metode standar diperoleh berat isi kering maksimum $\left(\gamma \mathrm{d}_{\text {maks }}\right)$ dan kadar air optimum $\left(\mathrm{w}_{\mathrm{opt}}\right)$. Dari hasil pengujian terdapat diperoleh berat isi kering maksimum $(\gamma \mathrm{d}$ maks $) 1,51 \mathrm{gr} / \mathrm{cm}^{3}$ dan kadar air optimum $\left(\mathrm{w}_{\mathrm{opt}}\right)$ 22,78\%. Hal ini menunjukkan bahwa parameter kepadatan ini sebagai bahan untuk sampel pengujian Unconfined Compressive Strength (UCS

\section{e. Unconfined Compressive Strength (UCS)}

Adapun hasil pengujian UCS kondisi peram 7 hari mempunyai nilai UCS terbesar $3.52 \mathrm{~kg} / \mathrm{cm}^{2}$ pada saat regangan $1,78 \%$. Menurut Hardiyatmo (2006), bahwa sampel tanah ini termasuk dalam 
kelompok konsistensi lempung sangat kaku karena nilai UCS pada rentang $2-4 \mathrm{~kg} / \mathrm{cm}^{2}$.

\section{Tanah lempung distabilisasi dengan pasir}

Adapun tanah lempung distabilisasi dengan pasir untuk mendapatkan hubungan indeks plastisitas tanah (PI) dengan variasi campuran pasir seperti terlihat pada Gambar 4.1 berikut.

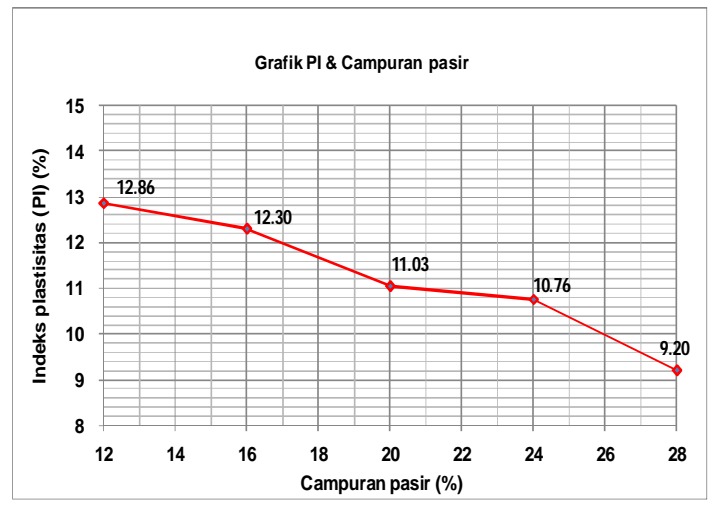

Gambar 4.1 Grafik hubungan PI dengan campuran pasir

Sumber: Hasil analisis (2016)

Dari Gambar 4.1 di atas terlihat, bahwa nilai PI makin menurun seiring bertambahnya campuran pasir. Namun pada saat campuran $12 \%$ pasir hanya mempunyai nilai indeks plastisitas (PI) $>10 \%$. Ini membuktikan bahwa tanah belum memenuhi syarat distabilisasi semen karena menurut Hicks (2002) bahwa tanah distabilisasi dengan semen sebaiknya tanah tersebut jika $>25 \%$ lolos saringan No. 200 dan memiliki PI $\leq 10 \%$. Pada campuran 16, 20, 24 pasir diperoleh nilai PI makin menurun namun PI masih di atas $10 \%$. Namun pada saat campuran $28 \%$ pasir diperoleh PI < $10 \%$ yaitu $9.20 \%$, sehingga tanah ini memenuhi syarat distabilisasi semen

Berdasarkan analisis di atas, bahwa tanah ini memenuhi syarat distabilisasi semen apabila campuran pasir minimum 28\%. Pada penelitian ini, akan dilakukan campuran pasir yang mewakili nilai $\mathrm{PI} \leq 10 \%$ antara lain campuran pasir $28 \%$.

\section{Tanah lempung sebelum dan sesudah penambahan matos terhadap stabnilisasi pasir dan semen}

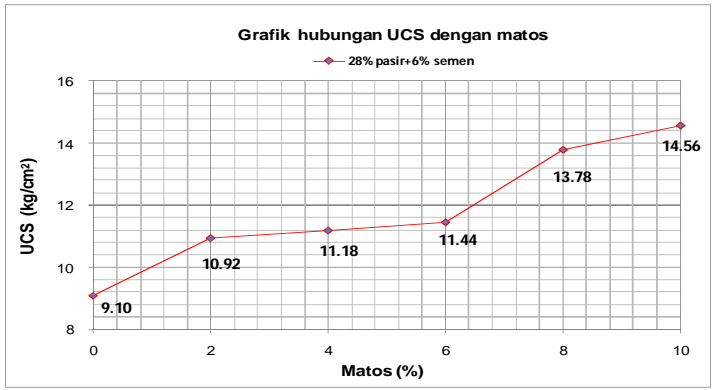

Gambar 4.2 Grafik hubungan UCS dengan Matos

Sumber: Hasil analisis (2016)

Pada Gambar 4.2 terlihat di atas, bahwa nilai UCS mengalami peningkatan seiring bertambahnya matos. Pada saat $0 \%$ matos pada stabilisasi campuran $28 \%$ pasir dan $6 \%$ semen nilai UCS sebesar $9.10 \mathrm{~kg} / \mathrm{cm}^{2}$. Kemudian, pada saat $2 \%$ matos, nilai UCS makin bertambah didapatkan $10.92 \mathrm{~kg} / \mathrm{cm}^{2}$ dan bahkan $4 \%$ nilai UCS makin meningkat hingga $11.18 \mathrm{~kg} / \mathrm{cm}^{2}$. Kemudian, pada saat $6 \%$ matos nilai UCS terus makin bertambah hingga $11.44 \mathrm{~kg} / \mathrm{cm}^{2}$ dan pada penambahan $8 \%$ matos, nilai UCS terjadi peningkatan cukup besar yaitu $13.78 \mathrm{~kg} / \mathrm{cm}^{2}$. Sedangkan pada penambahan $10 \%$ matos juga mengalami kenaikan nilai UCS cukup besar dengan nilai UCS $14,56 \mathrm{~kg} / \mathrm{cm}^{2}$.

Jika dilihat dari besaran nilai UCS ini, maka bahan tambah matos dapat meningkatkan nilai UCS dan memenuhi syarat sebagai subbase dan base jalan raya. Karena menurut Ingels dan Metcalf, 1972 (dalam Hardiyatmo, 2010), bahwa nilai UCS hasil > $7 \mathrm{~kg} / \mathrm{cm}^{2}$ dapat dipergunakan sebagai subbase dan base jalan raya.. Sedangkan menurut Ditjen Bina Marga yang didasarkan pada SNI 03-3438-1994 (dalam Hardiyatmo, 2010), bahwa campuran ini belum dapat dipergunakan sebagai subbase dan base jalan raya, karena nilai UCS hasil $<20 \mathrm{~kg} / \mathrm{cm}^{2}$.

Pada uji UCS ini semakin besar penambahan campuran semen dengan pasir maka semakin meningkat nilai UCS. Hal ini menunjukkan tanah semakin baik kuat tekannya disebabkan terisinya rongga pori tanah oleh penambahan pasir kemudian terjadi reaksi dalam tanah oleh penambahan semen dan air yang mengakibatkan tanah menjadi padat dan kuat. 


\section{PENUTUP}

\section{Kesimpulan}

Berdasarkan hasil penelitian, maka dapat diberi kesimpulan antara lain :

1. Kuat tekan bebas (UCS) tanah lempung Desa Baringin sebelum distabilisasi pasir dan semen sebesar $3.51 \mathrm{~kg} / \mathrm{cm}^{2}$

2. Kuat tekan bebas (UCS) $0 \%$ matos terhadap stabilisasi tanah lempung dengan semen sebesar $9.10 \mathrm{~kg} / \mathrm{cm}^{2}$

3. Kuat tekan bebas (UCS) tanah setelah penambahan $2 \%$ matos, nilai UCS $10.92 \mathrm{~kg} / \mathrm{cm}^{2}$ dan $4 \%$ matos nilai UCS $11.18 \mathrm{~kg} / \mathrm{cm}^{2}$. Kemudian, $6 \%$ matos nilai, UCS $11.44 \mathrm{~kg} / \mathrm{cm}^{2}$ dan $8 \%$ matos, nilai UCS $13.78 \mathrm{~kg} / \mathrm{cm}^{2}$. Sedangkan $10 \%$ matos, nilai UCS 14,56 $\mathrm{kg} / \mathrm{cm}^{2}$.

\section{Saran}

Berdasarkan kesimpulan di atas, maka perlu disarankan sebagai berikut:

1. Bahan tambah matos dapat meningkatkan kuat tekan tanah, namun perlu dilakukan penelitian lanjutan dengan tanah berbutir halus, tanah berbutir kasar dengan lokasi yang berbeda.

2. Bahan tambah matos $1 \mathrm{~kg} / \mathrm{m}^{3}$ perlu dilakukan pembanding dengan prosentase dengan penelitian ini

\section{DAFTAR PUSTAKA}

Hardiyatmo, H.C, 2010, Stabilisasi Tanah Untuk Perkerasan Jalan, Gajah Mada University Press, Yogyakarta.

Hardiyatmo, H.C, 2012, Mekanika Tanah 1, Edisi Keenam, Gajah Mada University Press, Yogyakarta.

Hasanuddin, 2011, Analisis Pemakaian Matos Sebagai Bahan Tambah Pada Stabilisasi Tanah Lempung Dengan Kapur, Penelitian Tesis Program Magister Teknik Sipil Universitas Islam Riau.

Hasanuddin. 2011, Analisis Pemakaian Matos Sebagai Bahan Tambah Pada Stabilisasi Tanah Lempung Dengan Kapur, Penelitian
Tesis Program Magister Teknik Sipil Universitas Islam Riau.

http://unitedgank007.blogspot.co.id/2016/01/pema datan-tanah.html

http://www.diskusilepas.com, Margin Error, diakses 13 Desember 2015

Ingles, O.G, dan Metcalf, J.B, (1972), Soil stabilization Principle and Practice, Butterworths Pty. Limited, Melbourne

Kretjie dan Morgan (www. slideshare.net), diakses 6 Agustus 2014.

Muda. A, 2011, Stabilisasi Tanah Lempung Bukit Rawi Menggunakan Pasir dan Semen, Tesis, Program Studi Magister Teknik Sipil Universitas Lambung Mangkurat, Banjarmasin.

SNI 03-1966-1990, Metode Pengujian Batas Plastis Tanah.

SNI 1742:2008, Pengujian Kepadatan Ringan Untuk Tanah.

SNI 1964:2008, Cara Uji Berat Jenis Tanah.

SNI 1965:2008, Cara Uji Penentuan Kadar Air Untuk Tanah dan Batuan di Laboratorium.

SNI 3423:2008, Cara Uji Analisis Ukuran Butir Tanah.

Widodo, $\mathrm{T}$ dan Qosari, 2011, Efektifitas Penambahan Matos Pada Stabilisasi Semen Tanah Berbutir Halus", yang dipublikasikan pada Jurnal Teknik Sipil Volume 1, Nomor 2, Oktober 2011, ISSN 2088-3676, Jurusan Teknik Sipil Universitas Janabadra, Yogyakarta. 